\title{
Antimicrobial and anti-HCV activity of triterpenoid and alkaloid compounds from Melochia umbellata (Houtt.) Stapf var Visenia (Paliasa)
}

\author{
Sapriansyah Nusan ${ }^{1}$, Nunuk Hariani Soekamto ${ }^{1 *}$, Firdaus Firdaus ${ }^{1}$, Yana Maolana Syah ${ }^{2}$ \\ ${ }^{1}$ Hasanuddin University, Kota Makassar, Indonesia. \\ ${ }^{2}$ Bandung Institute of Technology, Kota Bandung, Indonesia.
}

\begin{tabular}{|c|c|}
\hline ARTICLE INFO & ABSTRACT \\
\hline $\begin{array}{l}\text { Received on: } 29 / 11 / 2019 \\
\text { Accepted on: } 26 / 02 / 2020 \\
\text { Available online: } 04 / 04 / 2020\end{array}$ & $\begin{array}{l}\text { Two triterpenoid and alkaloid compounds have been isolated, namely, 3-acetyl-12-en-28-oic acid and (R)- } N \text {-trans- } \\
\text { feruloyloctopamine from Melochia umbellata (Houtt.) Stapf var Visenia. Both of these compounds were tested as } \\
\text { an antimicrobial and anti-HCV activity. Isolation has been done by maceration, fractionation, and purification. The } \\
\text { molecular structure was determined by IR spectroscopy and nuclear magnetic resonance (NMR) 1,2D ( }{ }^{1} \mathrm{H}-\mathrm{NMR} \text {, }\end{array}$ \\
\hline $\begin{array}{l}\text { Key words: } \\
\text { Triterpenoid, alkaloid, } \\
\text { Melochia umbellata, } \\
\text { antimicrobial, anti-HCV. }\end{array}$ & $\begin{array}{l}\left.{ }^{13} \mathrm{C}-\mathrm{NMR}, \mathrm{HSQC} \text {, and } \mathrm{HMBC}\right) \text {. Antimicrobial assay of } 3 \text {-acetyl-12-en-28-oic acid showed a zone of inhibition in the } \\
\text { criteria of moderate to active against Escherichia coli }(8.4 \mathrm{~mm}) \text {, Salmonella thypi }(11.2 \mathrm{~mm}) \text {, Staphylococcus aureus } \\
(10.8 \mathrm{~mm}) \text {, and Candida albicans }(8.5 \mathrm{~mm}) \text {, as well as compounds }(\mathrm{R})-N \text {-trans-feruloyloctopamine that is against } \\
\text { E. coli }(7.0 \mathrm{~mm}), S \text {. thypi }(10.55 \mathrm{~mm}), S \text { aureus }(9.1 \mathrm{~mm}) \text {, and } C \text {. albicans }(7.9 \mathrm{~mm}) \text {. Anti-HCV tests on the two } \\
\text { compounds showed } \mathrm{IC}_{50} \text { values of } 52.07 \text { and } 45.02 \mu \mathrm{g} / \mathrm{ml} \text {, respectively. The results of these tests indicate that the two } \\
\text { compounds are potential as an antibiotic candidate. }\end{array}$ \\
\hline
\end{tabular}

\section{INTRODUCTION}

Microbial infections, such as bacteria, fungi, and viruses, are a cause of morbidity and mortality worldwide (Ndhlala et al., 2013). Some diseases caused by microbial infections include tuberculosis, typhus, diphtheria, cholera, dysentery, and pneumonia (Wagner et al., 2017). While viral infections can cause various diseases, like hepatitis $\mathrm{C}$, it is also a worrying global problem (Emanuelli et al., 2014), infecting nearly 170 million people worldwide (Mustopa et al., 2012; Tumewu et al., 2016). Hepatitis $\mathrm{C}$ virus is a member of the genus Hepacivirus and the family Flaviviridae (Adianti et al., 2014). This disease is difficult to cure because there are no specific drugs or vaccines, such as hepatitis A and B (Mustopa et al., 2012), with increasing cases (Hsueh et al., 2016). HCV can cause acute liver disease and cirrhosis liver which can potentially lead to liver cancer (Mustopa et al., 2012).

\section{*Corresponding Author}

Nunuk Hariani Soekamto, Hasanuddin University, Kota Makassar, Indonesia.E-mail:nunukhariani@unhas.ac.id
Increased resistance to antibiotic and anti-HCV drugs requires the search for new antibiotic and anti-HCV drugs. Plants are a source of secondary metabolites with diverse molecular structures that can be used as drug candidates or lead compounds in the discovery and development of new drugs (Gupta et al., 2014; Li et al., 2013).

Melochia is a genus of the Malvaceae family, spread from India to Southeast Asia and Papua New Guinea. Currently, the genus Melochia is reported to consist of 65 species (Machado and Sazimab, 2008). Melochia umbellata (Houtt.) Stapf is one of the species of medicinal plants of the genus Melochia on Sulawesi Island (Indonesia). This species consist of two varieties, namely, degrabrata and visenia variety. Some studies on this species show a variety of chemicals, such as flavonoids, terpenoids, coumarin, alkaloids, and quinones.

Some compounds and bioactivity of M. umbellata (Houtt) var Degrabrata have been reported, such as stigmast-5,22-dien3O-B-D-glucopyranoside against Aspergillus niger (Ridhay et al., 2012), and 3-acetyl-12-oleanan-28-oic-acid active against Bacillus subtilis and C. albicans (Usman et al., 2014). 6,6'-dimethoxy-4,4'dihydroxy-3', 2'-furano-isoflavan compounds (Erwin et al., 2010), 
methyl b-(p-hydroxyphenyl) acrylic (Soekamto et al., 2008), and walterion $C$ exhibit anticancer activity (Erwin et al., 2014). The leaf extract of $M$. umbellata (Houtt) Stapf var degrabrata can protect inflammation of the liver (Raflizar and Sihombing, 2009), antioxidant activity, and moderate cytotoxic activity against HepG2 liver cancer cells (Arung et al., 2009).

The finding of the phenol alkaloid (R)-N-transferuloyloctopamine (2) compound from the plant $M$. umbellata (Houtt.) Stapf var Visenia has been reported previously (Nusan et al., 2019). In this paper together with a compound of 3-acetyl12-en-28-oic acid, the activity of both compounds as antimicrobial and anti-HCV will be reported. The molecular structure of (R)- $N$ trans-feruloyloctopamine (2) is shown in Figure 1.

\section{MATERIALS AND METHODS}

A liquid vacuum chromatography equipment, press column chromatography, gravity column chromatography, thinlayer chromatography, and chromototron were used for isolation; Fisher John melting point apparatus was used to determine the melting point of the compounds. The Fourier-transform infrared spectroscopy (FTIR) 8,501 Shimadzu and ${ }^{1} \mathrm{H}-\mathrm{NMR}$ Agilent 500 were used in spectroscopy.

\section{Materials}

Materials used in this study are a sample of the root timber of M. umbellata (Houtt) Stapf var. Visenia. The sample was determined by Keragaman Flora Indonesia, Makassar (Indonesia). The organic solvent used quality p.a and technical that is $n$-hexane, chloroform, ethyl acetate, acetone and methanol, silica gel Merck $(7,730,7,733$, and 7,734$)$, and cerium sulfate solution $2 \%$.

\section{Isolation and spectroscopic analysis}

The extraction is done by the total maceration method. First, the root timber powder M. umbellata (Houtt.) Stapf var Visenia was macerated using methanol and then partitioned liquid-liquid using a solvent: $n$-hexane, chloroform, ethyl acetate, and methanol. Each filtrate obtained was then evaporated until is obtained a viscous extract of each fraction, namely: fraction $n$-hexane, ethyl acetate, and methanol. Each fraction obtained is then weighed to find out its weight. Purification was carried out using chromatographic techniques, such as liquid vacuum chromatography, press column chromatography, gravity column chromatography, and chromototron with the appropriate eluents. The purity test was performed using thin layer chromatography analysis and melting point measurements.

The molecular structure was determined by IR spectroscopy, nuclear magnetic resonance (NMR) $1 \mathrm{D}$ and 2D $\left({ }^{1} \mathrm{H}-\mathrm{NMR},{ }^{13} \mathrm{C}-\mathrm{NMR}, \mathrm{HSQC}, \mathrm{HMBC}\right.$, and TOCSY).

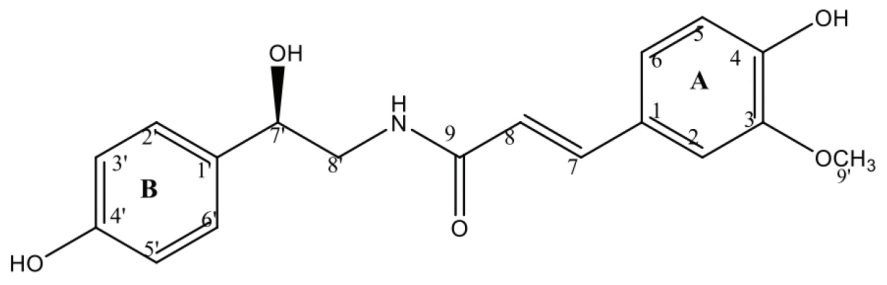

Figure 1. The molecular structure of (R)-N-trans-feruloyloctopamine (2).

\section{Antimicrobial assay}

Antimicrobial testing uses Gram-positive bacteria (E. coli and S. thypi), Gram-negative bacteria (S. aureus), and C. albicans fungus. An antibacterial and antifungal assay using the agar diffusion method. Antibacterial testing uses the muller hilton agar (MHA) medium, while the antifungal test uses the potato dextrose agar (PDA) media.

The antibacterial test was carried out using pure compounds with a certain concentration variation being dropped on each disc paper by using a micropipette. Paper discs are left to dry. Furthermore, the MHA media was added to the test bacteria using a micropipette, agar media that had been added to the test bacteria vortex, poured into a sterile petri dish, and shaken so that the bacteria mixed evenly with the MHA media. The media is allowed to stand in aseptic laminar until it is frozen. Each disc paper was placed in a cup using sterile tweezers and incubated at $37^{\circ} \mathrm{C}$ for $18-24$ hours. The antibacterial activity can be seen by observing the zone of inhibition formed around the disc paper. After finding out the diameter of the inhibition zone formed on the petri dish, the width of the inhibition zone formed using the calipers was measured. The amount of the inhibition zone is measured by reducing the inhibition zone formed on the test petri dish with the diameter of the disc paper.

The antifungal assay is carried out with the same procedure as an antibacterial assay, but using PDA media.

\section{Analysis of anti-HCV activities}

Seeding was performed in 48 wells with a cell density of $5.4 \times 10^{4}, 24$-hour incubation. After incubation add JFH1a virus titer $6.9 \times 10^{6}$ with m.o.i 0.1 and the sample in each well is $100 \mu 1$ from each dilution. In this study, concentrations of test materials were made 100, 50, 25, 12.5, 6.2, 3.1, and $1.56 \mu \mathrm{g} / \mathrm{ml}$. Furthermore, 48 hours of incubation were carried out and supernatant from each concentration was taken to calculate the titer. The calculation of infected cell titer is done using the same method, namely, on a multiwell plate 96 well. Next, it was incubated for 48 hours and was fixed for further staining using DAB thermo staining. Infected cells show a brown color. The inhibition percentage of virus infectivity by the samples was calculated by comparing to the control using SPSS probit analysis, and $\mathrm{IC}_{50}$ values were determined.

\section{RESULTS AND DISCUSSION}

\section{Isolation}

The plants bark powder of $M$. umbellata var. Visenia plants $(10 \mathrm{~kg})$ were extracted by maceration with methanol $1 \times 24$ hours (three times). The methanol extract was concentrated by a low-pressure rotary evaporator and methanol extract (116.26 g) was obtained. The methanol extract was partitioned with liquid-liquid extraction using solvents with increasing polarity; $n$-hexane, chloroform, and ethyl acetate. At the root timber obtained $n$-hexane extract as much as $10.24 \mathrm{~g}$, chloroform extract $41.28 \mathrm{~g}$, and ethyl acetate $11.1 \mathrm{~g}$.

Extract $n$-hexane as much as $10.0 \mathrm{~g}$ was fractionated using a vacuum liquid chromatography method using $n$-hexane eluent $(100 \%), n$-hexane: ethyl acetate in stages from a ratio of 19:1 to $1: 9$, ethyl acetate $(100 \%)$, and methanol (100\%), obtained 
4 fractions (A-D), namely, fraction A $(0.23 \mathrm{~g})$, fraction B (4.89 $\mathrm{g})$, fraction $\mathrm{C}(2.60 \mathrm{~g})$, and fraction $\mathrm{D}(0.57 \mathrm{~g})$. The profile spot of $n$-hexan extract is shown in Figure 2.

Fraction $\mathrm{C}$ as much as $2.00 \mathrm{~g}$ was carried out press column chromatography using eluent $n$-hexane: ethyl acetate with a ratio 9.5:0.5, 9:1, 8:2, 3:7, and $1: 1$, resulting in six subfractions (Ca-Cf) namely, subfraction of $\mathrm{Ca}(0.41 \mathrm{~g})$, subfraction of C.b (0.81 g), subfraction of C.c $(0.26 \mathrm{~g})$, subfraction of C.d ( $0.19 \mathrm{~g})$, subfraction of C.e $(0.21 \mathrm{~g})$, and subfraction of C.f $(0.20 \mathrm{~g})$. Furthermore, as much as $200 \mathrm{mg}$ of subfraction C.b was fractionated by the chromototron method using eluent $n$-hexane:chloroform with a ratio of 7:3, resulting in five sub-subfractions namely, C.b1 (0.003 g), C.b2 (0.004 g), C.b3 (0.012 g), C.b4 (0.033 g), and C.b5 $(0.057 \mathrm{~g})$. The $\mathrm{Cb} .5$ is fractionated again by the gravity column chromatography method using eluent $n$-hexane : diisoprophyl ether with a ratio of 8:2, resulting in three sub2-subfractions, namely, C.b51 (7.0 mg), C.b52 (11 mg), and C.b53 (17 mg). The C.b51 in the form of a white crystal weighing $7.0 \mathrm{mg}$ in thin layer chromatography analysis showed a single stain reinforced by sharp melting point intervals, indicating that the compound was pure (1). The profile spot of compound (1) is shown in Figure 3.

\section{Elucidation structure (1)}

Compound (1) formed white crystals with melting point $280^{\circ} \mathrm{C}-282^{\circ} \mathrm{C}$. The IR Spectrum Compound (1) shows the absorption at wave number $3,217.27 \mathrm{~cm}^{-1}$ for $\mathrm{OH}$, strong and sharp absorption at $1,728.22 \mathrm{~cm}^{-1}$ and $1,681.63 \mathrm{~cm}^{-1}$ for the carbonyl group $(\mathrm{C}=\mathrm{O})$ for esters and carboxylic acids and $1,251.80 \mathrm{~cm}^{-1}$ for $\mathrm{C}-\mathrm{O}$ ester single bonds and $1,028.06 \mathrm{~cm}^{-1}$ for $\mathrm{C}-\mathrm{O}$ carboxylic acid single bonds. The strong and sharp absorption band at 2,943.37 $\mathrm{cm}^{-1}$ as a $\mathrm{C}-\mathrm{H}$ bond of aliphatic reinforced by absorption band at

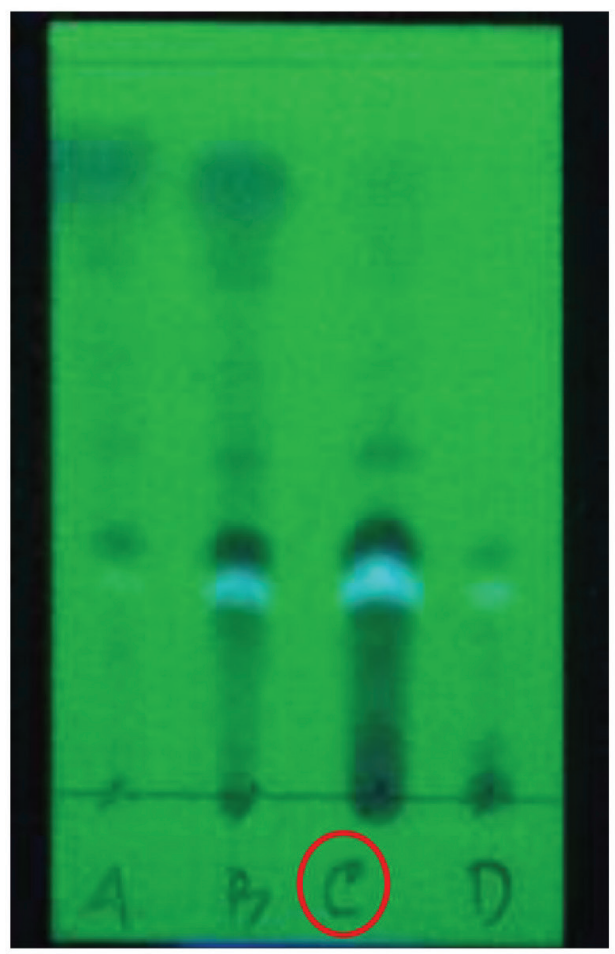

Figure 2. The profile spot of $n$-hexan extract.
$1,463.97 \mathrm{~cm}^{-1}$ which is the $\mathrm{C}-\mathrm{H}$ bending of the $\mathrm{CH}_{2}$ group. The IR Spectrum of compound (1) is shown in Figure 4.

The ${ }^{1} \mathrm{H}-\mathrm{NMR}$ spectrum shows the presence of proton signals in the chemical shift at $\delta_{\mathrm{H}} 5.28 \mathrm{ppm}$ as signal of $1 \mathrm{H}(\mathrm{H}-12)$ and 8 signals of $3 \mathrm{H}$ that is $\delta_{\mathrm{H}} 0.87 \mathrm{ppm}(\mathrm{H}-23), \delta_{\mathrm{H}} 0.86 \mathrm{ppm}(\mathrm{H}-$ $24), \delta_{\mathrm{H}} 0.95 \mathrm{ppm}(\mathrm{H}-25), \delta_{\mathrm{H}} 0.75 \mathrm{ppm}(\mathrm{H}-26), \delta_{\mathrm{H}} 1.14 \mathrm{ppm}(\mathrm{H}-27)$, $\delta_{\mathrm{H}} 0.91 \mathrm{ppm}(\mathrm{H}-29), \delta_{\mathrm{H}} 0.94 \mathrm{ppm}(\mathrm{H}-30)$, and $\delta_{\mathrm{H}} 2.05 \mathrm{ppm}(\mathrm{H}-32)$.

The ${ }^{13} \mathrm{C}$-NMR spectrum showed 32 carbon signals in the chemical shift between $\delta_{\mathrm{C}} 15.37 \mathrm{ppm}$ to $183.43 \mathrm{ppm}$. In the aliphatic region, 28 carbons were found, including one signal of a hydroxyl methine carbon at $\delta_{\mathrm{C}} 80.91 \mathrm{ppm}(\mathrm{C}-3)$. In the alkene region, signal $=\mathrm{CH}$-alkene was found at $\delta_{\mathrm{C}} 122.54 \mathrm{ppm}(\mathrm{C}-12)$ and signal $=\mathrm{C}$-quartener at $\delta_{\mathrm{C}} 143.58 \mathrm{ppm}(\mathrm{C}-13)$. Whereas in the carbonyl group region found a carbonyl group at $\delta_{\mathrm{C}} 183.43 \mathrm{ppm}$ (C-28) which was identified as the carboxylic acid and carbonyl group at $\delta_{\mathrm{C}} 171.00 \mathrm{ppm}\left(\mathrm{C}-1^{\prime}\right)$ which was identified as the ester.

Based on the HSQC spectrum, it can be explained that in the aliphatic carbon region there are 22 correlations, with details of 8 methyls $\left(\mathrm{CH}_{3}\right), 10$ methylenes $\left(\mathrm{CH}_{2}\right)$, and 4 methines $(\mathrm{CH})$. In the alkene region, one methine $(=\mathrm{CH})$ was identified at $\delta_{\mathrm{C}} 122.54$ ppm (C-12). The quaternary carbon was found in the alkene region at $\delta_{\mathrm{C}} 143.58 \mathrm{ppm}(\mathrm{C}-13)$, carbonyl groups at $\delta_{\mathrm{C}} 171.00 \mathrm{ppm}(\mathrm{C}-$ $28)$ as the ester, and carbonyl groups at $\delta_{\mathrm{C}} 183.43 \mathrm{ppm}\left(\mathrm{C}-1^{\prime}\right)$ as the carboxylic acid. The molecular formula for this compound is $\mathrm{C}_{32} \mathrm{H}_{50} \mathrm{O}_{4}$, which has a $\mathrm{DBE}$ value of 8 , with the details of 1 $\mathrm{DBE}$ for the alkene double bond (C-12/C-13), 2 DBE for the double bond on the carbonyl ester and carboxylate. Therefore, the

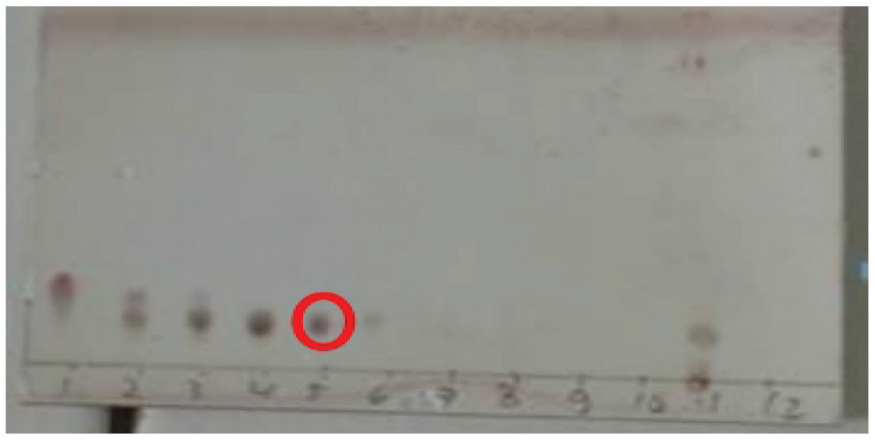

Figure 3. The profile spot of compound (1).

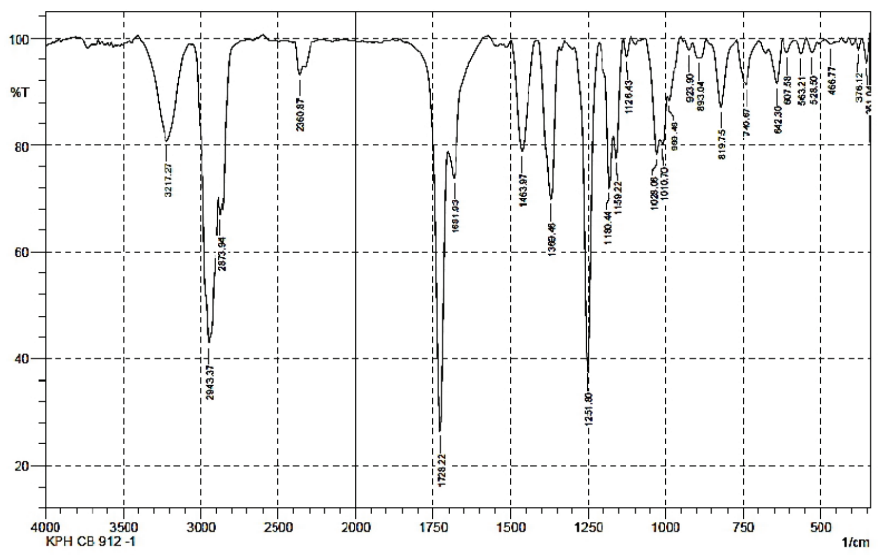

Figure 4. The FTIR spectrum of compound (1). 
remaining 5 DBE must be 5 rings. Thus this compound is a 5 -ring cyclic compound, which having one alkene bond at $\mathrm{C}-12,13$, and substituent of methyl, hydroxyl, carboxylic, and ester. Based on these characteristics, this compound is recommended to be the skeleton of a pentacyclic triterpenoid.

The HMBC data of the compound of (1) showed that protons at $\delta_{\mathrm{H}} 0.87 \mathrm{ppm}(\mathrm{H}-23)$ correlated distance with quaternary carbon at $\delta_{\mathrm{C}} 37.68 \mathrm{ppm}(\mathrm{C}-4)$, methoxy carbon at $\delta_{\mathrm{C}} 80.91 \mathrm{ppm}$ (C-3), methyl carbon at $\delta_{\mathrm{C}} 55.28 \mathrm{ppm}(\mathrm{C}-5)$, and methyl carbon at $\delta_{\mathrm{C}} 16.65 \mathrm{ppm}(\mathrm{C}-24)$. These $\mathrm{HMBC}$ correlations explain that the two methyl groups that is at $\delta_{\mathrm{C}} 28.027 \mathrm{ppm}(\mathrm{C}-23)$ and $\delta_{\mathrm{C}}$ $16.65 \mathrm{ppm}(\mathrm{C}-24) \mathrm{ppm}$ both of which have geminal positions as substituents bound to the quartener carbon at $\delta_{\mathrm{C}} 37.68 \mathrm{ppm}(\mathrm{C}-4)$ at the ring $\mathrm{A}$ of the pentacyclic triterpenoid skeleton.

Methyl protons at $\delta_{\mathrm{H}} 1.14 \mathrm{ppm}(\mathrm{H}-27)$ correlate distance with quaternary carbon at $\delta_{\mathrm{C}} 143.58 \mathrm{pm}(\mathrm{C}-13)$, methylene carbon at $\delta_{\mathrm{C}} 27.65 \mathrm{ppm}(\mathrm{C}-15)$, quartener carbon at $\delta_{\mathrm{C}} 39.27 \mathrm{ppm}(\mathrm{C}-8)$, and carbon quartener at $\delta_{\mathrm{C}} 41.55 \mathrm{ppm}(\mathrm{C}-14)$. Methyl protons at $\delta_{\mathrm{H}} 0.76 \mathrm{ppm}(\mathrm{H}-26)$ correlate distance with quartener carbon at $\delta_{\mathrm{C}} 39.27 \mathrm{ppm}(\mathrm{C}-8)$, quartener carbon at $\delta_{\mathrm{C}} 41.55 \mathrm{ppm}(\mathrm{C}-14)$, methylene carbon at $\delta_{\mathrm{C}} 32.43 \mathrm{ppm}(\mathrm{C}-7)$, and methyl carbon at $\delta_{\mathrm{C}} 47.54 \mathrm{ppm}(\mathrm{C}-9)$, while methyl proton at $\delta_{\mathrm{C}} 0.94 \mathrm{ppm}(\mathrm{H}-25)$ correlates remotely with carbon methine at $\delta_{\mathrm{C}} 47.54 \mathrm{ppm}(\mathrm{C}-9)$, carbon methylene at $\delta_{\mathrm{C}} 38.06 \mathrm{ppm}(\mathrm{C}-1)$, and quaternary carbon at $\delta_{\mathrm{C}} 36.97 \mathrm{ppm}(\mathrm{C}-10)$. This HMBC correlation data explains that the methyl group at $\delta_{\mathrm{C}} 25.88(\mathrm{C}-27)$ is a substituent bound to the quartener carbon atom at $\delta_{\mathrm{C}} 41.55 \mathrm{ppm}(\mathrm{C}-14)$, the methyl group $17.15 \mathrm{ppm}(\mathrm{C}-26)$ as a substituent bound to quartener carbon at $\delta_{\mathrm{C}} 39.27 \mathrm{ppm}(\mathrm{C}-8)$, and methyl group at $\delta_{\mathrm{C}} 15.37 \mathrm{ppm}(\mathrm{C}-25)$ as substituents bound to carbon quaternary at $\delta_{\mathrm{C}} 36.97 \mathrm{ppm}(\mathrm{C}-10)$.

Methyl protons at $\delta_{\mathrm{H}} 0.91 \mathrm{ppm}(\mathrm{C}-29)$ correlate distance with methyl carbon at $\delta_{\mathrm{C}} 23.56 \mathrm{ppm}(\mathrm{C}-30)$, while methyl protons at $\delta_{\mathrm{H}} 0.94 \mathrm{ppm}(\mathrm{C}-30)$ correlate distance with quartener carbon at $\delta_{\mathrm{C}} 30.66 \mathrm{ppm}(\mathrm{C}-20)$ and secondary carbon atom at $\delta_{\mathrm{C}} 45.83 \mathrm{ppm}$. This HMBC data explains that both methyl are substituents with geminal positions that are bound to quartener carbon atoms at $\delta_{\mathrm{C}}$ $30.66 \mathrm{ppm}(\mathrm{C}-20)$, showing this compound is typical for $\beta$-amyrin. The proton methine at $\delta_{\mathrm{H}} 2.82 \mathrm{ppm}(\mathrm{H}-18)$ correlates distance with carbon methine $\mathrm{C}$-sp ${ }^{2}$ at $\delta_{\mathrm{C}} 122.54 \mathrm{ppm}$ and $\mathrm{C}$-sp ${ }^{2}$ quartener carbon at $\delta_{\mathrm{C}} 143.58 \mathrm{ppm}$ supporting these two $\mathrm{C}$ - $\mathrm{sp}^{2}$ as vinyl groups, respectively, in C-12 and C-13, confirm this compound as oleanen. Besides, the distance correlation between methyl protons at $\delta_{\mathrm{H}} 2.82 \mathrm{ppm}(\mathrm{H}-18)$ and quartener carbon at $\delta_{\mathrm{C}} 183.43 \mathrm{ppm}$ (C-28) confirms that the carboxyl group is a substituent bound to $\mathrm{C}-17$, which is common in oleanen containing carboxyl group.

Searching literature shows that compound (1) is a known oleanen, as well as that found in M. umbellata (Houtt.) Stapf var Degrabrata that is compound of 3-acetyl-12-oleanen28-oic acid (Usman et al., 2014). Data interpretation of ${ }^{1} \mathrm{H}-\mathrm{NMR}$, ${ }^{13} \mathrm{C}-\mathrm{NMR}$, HSQC, and HMBC data is presented in Table 1, while the correlation of HSQC, HMBC, and the molecular structure of compound (1) is shown in Figure 5.

\section{Biogenesis of (R)-N-trans-feruloyloctopamine (2)}

The biosynthesis of compounds (R)-N-transferuloyloctopamine in plants is generally thought to originate from condensation and reduction of octopamine and ferulic acid.
The two compounds are derived from a shikimate acid pathway starting from the condensation of erythrose-4P and PEP to produce 3-deoxy-D-arabino-heptulosonic acid 7-phosphate (DAHP). DAHP through a series of reactions, like aldol condensation, which involving several enzymes as catalysts, forming shikimic acid (Dewick, 2002; Parthasarathy et al., 2018). Through shikimic acid condensation and PEP, chorismic acid is formed, which then undergoes a series of rearrangement reactions to form prephenic acid (Dewick, 2002). Prephenic aminotransferase is an enzyme whose role is to convert prephenic acid into arogenic acid. Arogenate is the exclusive precursor of Phe/Tyr in many plants (Lewis and Yamamato, 1990).

Pathways to the aromatic amino acids L-phenylalanine and L-tyrosine via prephenic acid may vary according to the organism, and often more than one route may operate in a particular species according to the enzyme activities that are available (Dewick, 2002). In arogenic acid 2 new biogenesis pathways are formed, one dehydrogenates to form tyrosine and one dehydrates to form phenylalanine. Arogenate dehydratase is an enzyme that plays a role in the metabolism of L-phenylalanine, while arogenate dehydrogenase is a role in the metabolism of L-tyrosine. All enzymes synthesizing Phe/Tyr have been found in the chloroplast, some evidence suggests that a dual pathway may exist in the cytosolic (Lewis and Yamamoto, 1990).

Phenylalanine undergoes a deamination reaction to form cinnamic acid, which then undergoes a hydroxylation reaction to form p-coumaric acid. Ferulic acid undergoes oxygenation to form trans-caffeic acid (caffeoyl), then undergo methylation to form ferulic acid (Dewick, 2002). In other pathways, phenylalanine can undergo oxygenation to form tyrosin (Dewick, 2002; Parthasarathy et al., 2018). Tyrosine can also form a pathway to produce p-coumaric acid and its derivatives (Dewick, 2002). In another pathway, tyrosine decarboxylase converts L-Tyrosine to Tyramine, and tyramine is metabolized by the Tyramine $\beta$-hydroxylase to Octopamine (D'Andrea et al., 2019; Farooqui, 2012; Parthasarathy et al., 2018).

In the final, octopamine ( $p$-octopamine) condenses with ferulic acid to form (R) -N-trans-feruloyloctopamine. This condensation reaction is stereospecific in which a trans product is formed, followed by a reduction reaction in the form of the elimination of the $\mathrm{OH}$ group in ferulic acid. The organic reactions between octopamine and ferulic acid and other compounds in this group have been proven by a series of synthesis experiments of several researchers (Firdaus et al., 2018). However, it still needs to be understood that the biosynthesis of organic compounds in nature may be more complicated and not really the same as the synthesis process in the laboratory. The biogenesis pathway for compounds (R)-N-trans-feruloyloctopamine is shown in Figure 6.

\section{Antimicrobial and anti-HCV assay}

The results of the antimicrobial assay of compounds isolated against E. coli, S. typhi, S. aureus, and C. albicans are presented in Table 2.

A compound with an inhibition zone diameter of less than $5 \mathrm{~mm}$ is categorized as weak, inhibitory zones between $>5$ and $10 \mathrm{~mm}$ are categorized as a medium, inhibitory zones $>10-20 \mathrm{~mm}$ are categorized as strong, and inhibitory zones $>20$ 
Table 1. The interpretation data NMR 1,2D of 3-acetyl-12-en-28-oic acid (1).

\begin{tabular}{|c|c|c|c|c|c|}
\hline \multirow{2}{*}{ No. } & \multicolumn{2}{|c|}{ The compound (1) } & \multicolumn{2}{|c|}{ B-Amirin *) } & \multirow{2}{*}{ HMBC of the compound (1) } \\
\hline & ${ }^{1} \mathrm{H}-\mathrm{NMR}$ ppm $(\mathrm{I}, \boldsymbol{m}, \boldsymbol{J})$ & ${ }^{13} \mathrm{C}-\mathrm{NMR}$ ppm (Group) & ${ }^{1} \mathrm{H}-\mathrm{NMR}$ ppm $(\mathrm{I}, \mathrm{m}, \boldsymbol{J})$ & ${ }^{13}$ C-NMR (ppm) & \\
\hline \multirow{2}{*}{1.} & $1.63(1 \mathrm{H}, m)$ & \multirow{2}{*}{$38.06(\mathrm{CH} 2)$} & $1.76(t, 3.25 ; 7.8 ; 13.6)$ & \multirow{2}{*}{38.24} & \multirow{2}{*}{$\mathrm{C}-3$} \\
\hline & $1.07(1 \mathrm{H}, m)$ & & $1.23(1 \mathrm{H}, m)$ & & \\
\hline 2. & $1.63(2 \mathrm{H}, s)$ & $21.51(\mathrm{CH} 2)$ & $1.80(1 \mathrm{H}, m)$ & 23.70 & $\mathrm{C}-3$ \\
\hline 3. & $4.50(1 \mathrm{H}, t, 9.0)$ & $80.91(\mathrm{CH})$ & $4.50(t, 9,1)$ & 81.10 & C-24, C-23, C-31 \\
\hline 4. & - & $37.68(\mathrm{C})$ & - & 37.87 & - \\
\hline 5. & $0.84(1 \mathrm{H}, m)$ & $55.28(\mathrm{CH})$ & $1.30(1 \mathrm{H}, m)$ & 55.46 & - \\
\hline \multirow{2}{*}{6.} & $1.55(1 \mathrm{H}, m)$ & \multirow{2}{*}{$18.17\left(\mathrm{CH}_{2}\right)$} & $1.52(1 \mathrm{H}, m)$ & \multirow{2}{*}{18.35} & \multirow{2}{*}{ - } \\
\hline & $1.39(1 \mathrm{H}, m)$ & & $1.28(1 \mathrm{H}, m)$ & & \\
\hline \multirow{2}{*}{7.} & $1.78(1 \mathrm{H}, m)$ & \multirow{2}{*}{$32.43\left(\mathrm{CH}_{2}\right)$} & $1.56(1 \mathrm{H}, m)$ & \multirow{2}{*}{32.69} & \multirow{2}{*}{$\mathrm{C}-16, \mathrm{C}-21$} \\
\hline & $1.59(1 \mathrm{H}, s)$ & & $1.31(1 \mathrm{H}, m)$ & & \\
\hline 8. & - & $39.27(\mathrm{C})$ & - & 39.45 & - \\
\hline 9. & $1.58(1 \mathrm{H}, m)$ & $47.54(\mathrm{CH})$ & $1.43(1 \mathrm{H}, d d, 3.2$ dan 9.75$)$ & 47.73 & $\mathrm{C}-25, \mathrm{C}-26, \mathrm{C}-8$ \\
\hline 10. & - & $36.97(\mathrm{C})$ & - & 37.17 & - \\
\hline 11. & $1.88(2 \mathrm{H}, s, 3.0)$ & $23.38\left(\mathrm{CH}_{2}\right)$ & $1.97(1 \mathrm{H}, \mathrm{ddd}, 4.5 ; 9.1 ; 13.6)$ & 23.10 & - \\
\hline 12. & $5.28(1 \mathrm{H}, t, 3.5)$ & $122.54(\mathrm{CH})$ & $5.25(1 \mathrm{H}, t, 3.9)$ & 122.74 & - \\
\hline 13. & - & $143.58(\mathrm{C})$ & - & 143.78 & - \\
\hline 14. & - & $41.56(\mathrm{C})$ & - & 41.73 & - \\
\hline \multirow{2}{*}{15.} & $1.72(1 \mathrm{H}, d, 4)$ & \multirow{2}{*}{$27.66\left(\mathrm{CH}_{2}\right)$} & $1.38(1 \mathrm{H}, m)$ & \multirow{2}{*}{27.84} & \multirow{2}{*}{ - } \\
\hline & $1.09(1 \mathrm{H}, m)$ & & $1.13(1 \mathrm{H}, m)$ & & \\
\hline \multirow{2}{*}{16.} & \multirow{2}{*}{$1.99(2 \mathrm{H}, m)$} & \multirow{2}{*}{$22.88\left(\mathrm{CH}_{2}\right)$} & $1.61(1 \mathrm{H}, m)$ & \multirow{2}{*}{23.57} & \multirow{2}{*}{ - } \\
\hline & & & $1.36(1 \mathrm{H}, m)$ & & \\
\hline 17. & - & $46.50(\mathrm{C})$ & - & 46.72 & - \\
\hline 18. & $2.82(1 \mathrm{H}, d d, 3.5$ dan 13$)$ & $40.94(\mathrm{CH})$ & $2.86(1 \mathrm{H}, \mathrm{dd}, 4.55 ; 13.65)$ & 41.10 & C-17, C-19, C-12, C-16, C-14, C-13, C-28 \\
\hline 10 & $1.61(1 \mathrm{H}, m)$ & $450^{\circ}(\mathrm{CH})$ & $124 \mathrm{HH}$ & 160 & \\
\hline 19. & $1.17(1 \mathrm{H}, m)$ & $45.83\left(\mathrm{CH}_{2}\right)$ & $1.24(1 \mathrm{H}, m)$ & 46.0 & - \\
\hline 20. & - & $30.66(\mathrm{C})$ & - & 30.85 & - \\
\hline 21 & $1.35(1 \mathrm{H}, d, 4.5)$ & 2270 & 21 & 2260 & \\
\hline 21. & $1.22(1 \mathrm{H}, s)$ & $33 . / 8\left(\mathrm{CH}_{2}\right)$ & $1.31(1 \mathrm{H}, m)$ & 32.62 & - \\
\hline 22 & $1.44(1 \mathrm{H}, m)$ & $3252(\mathrm{CH})$ & $2.02(1 \mathrm{H}, m)$ & 3306 & 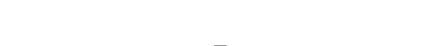 \\
\hline $2 z$. & $1.30(1 \mathrm{H}, m)$ & $32.52\left(\mathrm{CH}_{2}\right)$ & $1.77(1 \mathrm{H}, m)$ & 33.96 & - \\
\hline 23. & $0.87(3 \mathrm{H}, s)$ & $28.03\left(\mathrm{CH}_{3}\right)$ & $0.85(3 \mathrm{H}, s)$ & 28.22 & $\mathrm{C}-24, \mathrm{C}-4, \mathrm{C}-5, \mathrm{C}-3$ \\
\hline 24. & $0.86(3 \mathrm{H}, s)$ & $16.65\left(\mathrm{CH}_{3}\right)$ & $0.86(3 \mathrm{H}, s)$ & 16.84 & $\mathrm{C}-23$ \\
\hline 25. & $0.94(3 \mathrm{H}, s)$ & $15.37\left(\mathrm{CH}_{3}\right)$ & $0.93(3 \mathrm{H}, s)$ & 15.57 & C-10, C-1, C-9, C-5 \\
\hline 26. & $0.75(3 \mathrm{H}, s)$ & $17.15\left(\mathrm{CH}_{3}\right)$ & $0.74(3 \mathrm{H}, s)$ & 17.35 & C-7, C-8, C-14, C-9 \\
\hline 27. & $1.14(3 \mathrm{H}, s)$ & $25.88\left(\mathrm{CH}_{3}\right)$ & $1.12(3 \mathrm{H}, s)$ & 26.08 & $\mathrm{C}-15, \mathrm{C}-8, \mathrm{C}-14, \mathrm{C}-13$ \\
\hline 28. & - & $183.43(\mathrm{C})$ & - & 183.96 & - \\
\hline 29. & $0.91(3 \mathrm{H}, s)$ & $33.04\left(\mathrm{CH}_{3}\right)$ & $0.90(3 \mathrm{H}, s)$ & 32.84 & $\mathrm{C}-30$ \\
\hline 30. & $0.94(3 \mathrm{H}, s)$ & $23.56\left(\mathrm{CH}_{3}\right)$ & $0.94(3 \mathrm{H}, s)$ & 23.51 & C-20, C-21, C-29, C-19 \\
\hline $1^{\prime}$. & - & $171.00(\mathrm{C})$ & - & 171.25 & - \\
\hline $2^{\prime}$. & $2.05(3 \mathrm{H}, s)$ & $21.29\left(\mathrm{CH}_{3}\right)$ & $2.04(3 \mathrm{H}, s)$ & 22.06 & C- 31 \\
\hline
\end{tabular}

*Usman et al. (2014)

$\mathrm{mm}$ are categorized as very strong (Claude et al., 2014). Table 2 shows that compound (1) and Compound (2) are categorized as having moderate-to-strong inhibition against E. coli, S. typhi, S. aureus, and C. albicans. The antibacterial test data above shows the tendency of the two compounds as found in many antibiotic compounds, which have relatively stronger antibacterial activity against Gram-positive bacteria (E. coli dan S. typhi) than Gramnegative bacteria (S.aureus), perhaps is related to the cell wall layer of Gram-positive bacteria that are not as thick and as complex as Gram-negative bacteria.

The results of the anti-HCV assay 3-acetyl-12-oleanen28-oic acid (1) and (R)- $N$-trans-feruloyloctopamine (2) against JFH1a virus showed $\mathrm{IC}_{50}$ values of 52.07 and $45.02 \mu \mathrm{g} / \mathrm{ml}$, respectively. A compound is said to be active as anti-HCV if the $\mathrm{IC}_{50}$ value is less than $30 \mu \mathrm{g} / \mathrm{ml}$ (Versiaty et al., 2014), and can be categorized as very active if the $\mathrm{IC}_{50}$ value is less than 


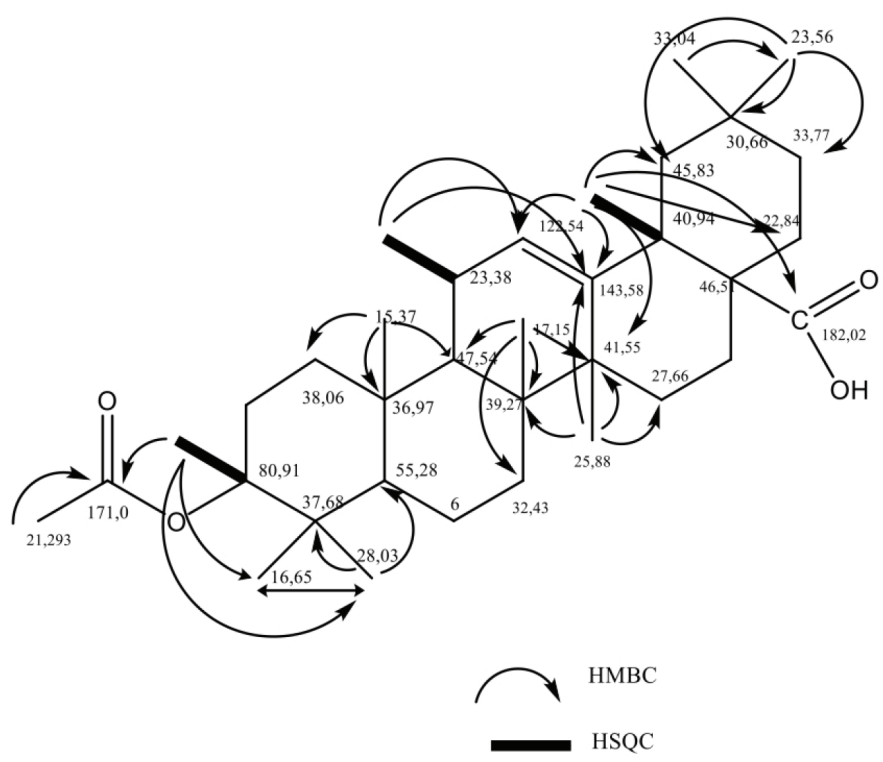

Figure 5. The molecular structure of 3-acetyl-12-oleanen-28-oic acid (1) from Melochia Umbellata (Houtt.) Stapf var Visenia.

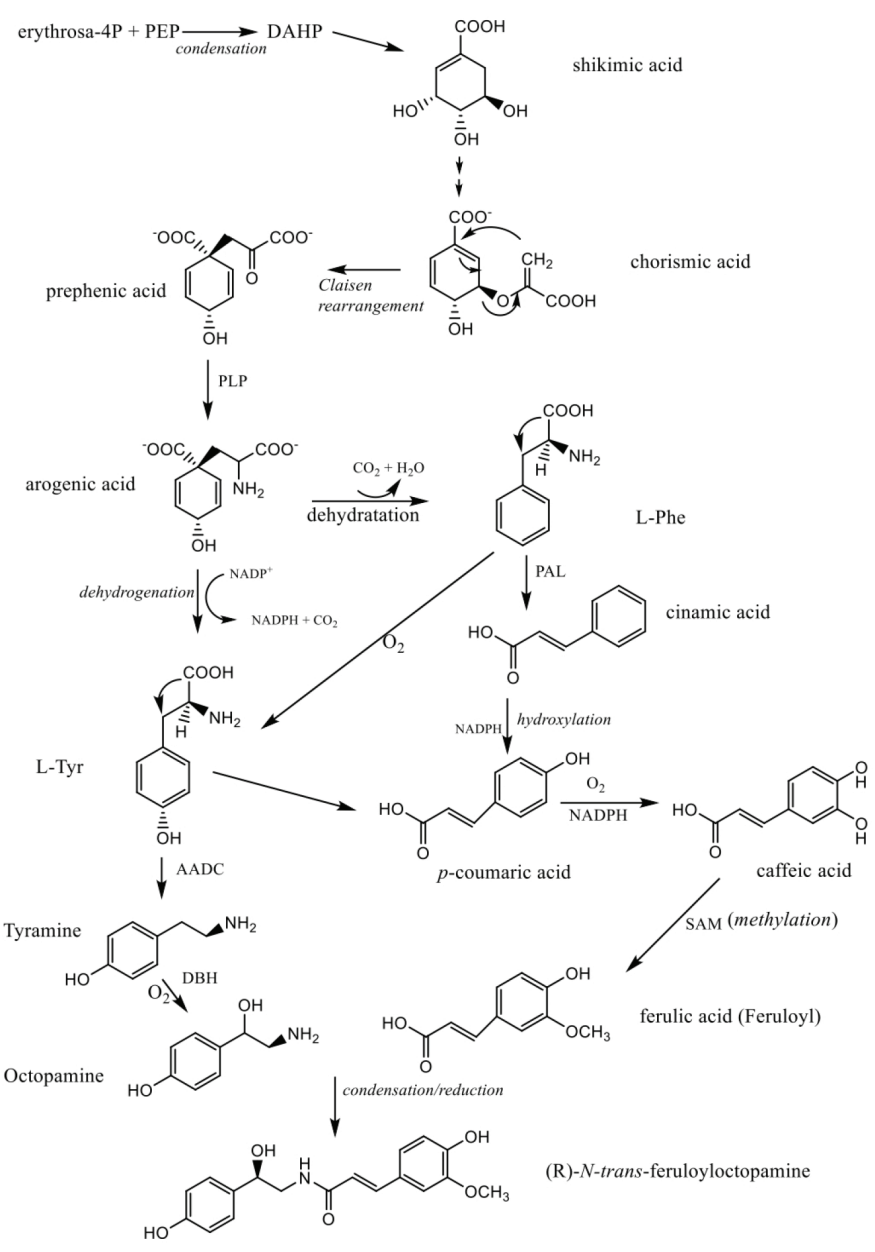

Figure 6. The biogenesis pathway of (R)-N-trans-feruloyloctopamine (2).
Table 2. The diameter of inhibitory zones of compounds isolated against microbes.

\begin{tabular}{lcccc}
\hline \multirow{2}{*}{ Compounds } & \multicolumn{4}{c}{ The diameter of inhibitory $(\mathbf{m m})$} \\
\cline { 2 - 5 } & E. coli & S. typhi & S. aureus & C. albicans \\
\hline 3-acetyl-12-oleanen-28 oic acid (1) & 8.4 & 11.2 & 10.8 & 8.5 \\
(R)- $N$-trans-feruloyloctopamine (2) & 7.0 & 10.55 & 9.1 & 7.9 \\
\hline
\end{tabular}

$5 \mu \mathrm{g} / \mathrm{ml}$ (Cao et al., 1998). Melochia umbellata (Houtt) Stapf var Visenia is one of the Paliasa species, in the province of South Sulawesi (Indonesia) used traditionally as an anti-liver drug in the form of extracts, but currently unknown active compounds as anti-liver (anti-hepatitis) activities (Raflizar and Sihombing, 2009; Noor et al., 2004). The results of the antihepatitis C test on the two compounds $(1,2)$ specifically showed that they were not responsible for the anti-liver activity of $M$. umbellata (Houtt.) Stapf var Visenia extract based on the $\mathrm{IC}_{50}$ values above, but it was suspected that both, specifically the compound (2) wich have $\mathrm{IC}_{50}$ values close to moderate, it contributes with other active compounds (unknown) to the antiliver activity of these plant extracts.

\section{CONCLUSION}

Has been isolated from the root timber of M. umbellata (Houtt) stapf var. visenia (Paliasa), a pentacyclic triterpenoid compound that is 3-acetyl-12-oleanen-28-oic acid. Compounds 3-acetyl-12-oleanen-28-oic acid and (R)- $N$-transferuloyloctopamine are potential as antibiotic candidates.

\section{ACKNOWLEDGMENTS}

The authors would like to thank the honorable head of the Organic Chemistry Laboratory at the Chemistry Department of Hasanuddin University who has provided the facilities to conduct this research, head of the Organic Chemistry Laboratory at the Bandung Institute of Technology, and staffs who have helped obtain NMR spectroscopic data. The authors also like to thank the Head of the Microbiology Laboratory at the Medical School of Hasanuddin University for antimicrobial assay and Head of the Institute of Tropical Disease, Airlangga University which has helped anti-HCV assay.

\section{CONFLICT OF INTEREST}

The authors declare that they have no conflicts of interest.

\section{REFERENCES}

Adianti M, Aoki C, Komoto M, Deng L, Shoji I, Wahyuni TS, Lusida MI, Soetjipto, Fuchino H, Kawahara N, Hotta H. Anti-hepatitis C virus compounds obtained from Glycyrrhiza uralensis and other Glycyrrhiza species. Microbiol Immun, 2014; 58:180-7.

Arung ET, Kusuma IW, Purwatiningsih S, Roh SS, Yang CH, Jeon S, Kim YU, Sukaton E, Susilo J, Astuti Y, Wicaksono BD, Sandra F, Shimizu K, dan Kondo R. Antioxidant activity and cytotoxicity of the traditional indonesian medicine tahongai (Kleinhovia hospita L.) extract. J Acupuncture Meridian Stud, 2009; 2:306-8.

Cao SG, Valerie HL, Wu XH, Sim KY, Tan BHK, Pereira JT, Goh SH. Novel cytotoxic Polyprenilated Xanthones from Gharchinia gaudichaudii. Tetrahedron, 1998; 54:10915-24. 
Claude TJ, Christine M, Songa B, Jeanne MM, Goretti IM, Claude CJ. chemical composition, antibacterial and antifungal activity of the essential oil of Phinus Patula growing in rwanda. Am J Biomed Life Sci, 2014; 2:55-9.

D'Andrea G, Pizzolato G, Gucciardi A, Stocchero M, Giordano G, Baraldi E, et al. Different circulating trace amine profiles in de novo and treated parkinson's disease patients. Sci Rep, 2019; 9(6151):1-11.

Dewick PM. Medicinal natural products: a biosynthetic approach. 2nd edition. Copyright by John Wiley \& Sons Ltd, Baffins Lane, Chichester, UK, 2002.

Emanuelli AMC, Pécheur EI, Chen Z. Benzhydrylpiperazine compounds inhibit cholesterol-dependent cellular entry of hepatitis $\mathrm{C}$ virus. Antivir Res, 2014; 109:141-8.

Erwin, Noor A, Soekamto NH, and Harlim T. 6,6'-Dimethoxy4,4'-Dihidroxy-3',2'-Furano Isoflavane, a New Compound From Melochia umbellata (Houtt.) Stapf var. Degrabrata K. (Paliasa). Indo J Chem, 2010; 10:222-5.

Erwin, Noor A, Soekamto NH, van Altena I, Maolana Syah Y Walterion $\mathrm{C}$ and cleomiscosin from Melochia umbellata var. Degrabrata K. (Malvaceae), biosynthetic and chemotaxonomic Significance. Biochem Syst Ecol, 2014; 55:358-61.

Farooqui T. Review of octopamine in insect nervous systems. Open Access Insect Physiol, 2012; 4:1-17.

Firdaus, Soekamto NH, Seniwati, Islam MF, Sultan. and amide of ferulic acids: synthesis and bioactivity against P388 leukemia murine cells. J Phys Conf Ser, 2018; 979(012016): 1-5.

Gupta P, Bhatnagar I, Kim SK, Verma AK, Sharma A. In-vitro cancer cell cytotoxicity and alpha-amylase inhibition effect of seven tropical fruit residues. Asian Pac J Trop Biomed, 2014; 4:S665-671.

Hsueh TP, Lin WL, Tsai TH. Pharmacokinetic interactions of herbal medicines for the treatment of chronic hepatitis. J Food Drug Anal, 2016; xxx:1-10.

Lewis NG, Yamamoto E. Lignin: occurrence, biogenesis and biodegradation. Plant Physiol Plant Mol BioI, 1990; 41:455-96.

Li YM, Tian Y, Shen L, Buettner R, Li HZ, Liu L, Yuan YC, Xiao Q, Wu J, Jove R. 3-O-methyl the spesilactam, a new small-molecule anticancer pan-JAK inhibitor against A2058 human melanoma cells. Biochem Pharmacol, 2013; 86:1411-18.

Machado IC, Sazima M. Pollination and breeding system of Melochia tomentosa L. (Malvaceae), a keystone floral resource in the Brazilian Caatinga. Flora, 2008; 203:484-90.

Mustopa AZ, Melki, Ika Sari Kusumawati. Isolasi dan Identifikasi Awal Senyawa Inhibitor RNA Helikase Virus Hepatitis C Dari ekstrak Buah Mangrove Avicennia marina (Forsk.). Vierh. JPHPI, 2012; 15:127-35.

Ndhlala AR, Amoo SO, Ncube B, Moyo M, Nair JJ, Van Staden J. Chapter 16: antibacterial, antifungal, and antiviral activities of african medicinal plants. Research Centre for Plant Growth and Development, School of Life Sciences, University of KwaZulu-Natal, Pietermaritzburg, South Africa: Medicinal Plant Research in Africa, pp 621-659, 2013.
Noor A, Kumanireng AS, Kartikasari R, Suryaningsih, Hakim A, Takbir A. Isolasi dan Identifikasi Konstituen Organik Tanaman Daun Paliasa (Kleinhovia hospita Linn.) Pada Kelarutan Berdasarkan Kelompok Polaritasnya. Marina Chimica Acta, 2004; 5:2-10.

Nusan S, Soekamto NH, Maolana Syah Y, Firdaus, Hermawati E. (R)-N-trans- feruloyloctopamine from the root timber of Melochia umbellata (Houtt.) Stapf var. Visenia (Paliasa). J Phys Conf Ser, 2019; 1341(032021):1-7.

Parthasarathy A, Cross PJ, Dobson RCJ, Adams LE, Savka MA, Hudson AO. A three-ring circus: metabolism of the three proteogenic aromatic amino acids and their role in the health of plants and animals. Front Mol Biosci, 2018; 5(29):1-30.

Raflizar R, \& Sihombing M. Dekok Daun Paliasa (Kleinhovia hospita Linn) Sebagai Obat Radang Hati Akut. Jurnal Ekologi Kesehatan, 2009; 8:984-93.

Ridhay A, Noor A, Soekamto NH, Harlim T, van Altena I. A stigmasterol glycoside from the root wood of Melochia umbellata (Houtt.) Stapf var Degrabrata K. Indo J Chem, 2012; 12:100-3.

Soekamto NH, Noor A, Dini I, Rudiyansyah, Garson M. Kumarin and steroid compound from stem bark of Kleinhovia hospita Linn. Proc Int Semin Chem, 2008; 231-34.

Tumewu L, Apryani E, Santi MR, Wahyuni TS, Permanasari AA, Adianti M, Aoki C, Widyawaruyanti A, Hafid AF, Lusida MI, Soetjipto, Hotta H. Antivirus hepatitis C Virus Activity of Alectryon serratus leaves extract. Procedia Chem, 2016; 18:169-73.

Usman, Soekamto NH, Usman H, Ahmad A. Toxicity and antimicrobial activity from extract and oleanan derivate compounds of the bark Melochia umbellata (Houtt.) Stapf Var. Degrabrata. Int J Pharm Bio Sci, 2014; 5:231-38

Versiaty TP, Hafid AF, Widyawaruyanti A. Aktivitas antiviral batang Eucalyptus globulus terhadap virus hepatitis C JFH1a. J Farmasi dan Ilmu Kefarmasian Indonesia, 2014; 1:16-9.

Wagner C, Gezelle JD, Robertson M, Robertson K, Wilson M, Komarnytsky S. Antibacterial activity of medicinal plants from the physicians of myddvai, a 13th-century Welshmedical manuscript. J Ethnopharmacol, 2017; 203:171-81.

How to cite this article:

Nusan S, Soekamto NH, Firdaus F, Syah YM. Antimicrobial and anti-HCV activity of triterpenoid and alkaloid compounds from Melochia umbellata (Houtt.) Stapf var Visenia (Paliasa). J Appl Pharm Sci, 2020; 10(04):135-141. 